\title{
PENGARUH LEVERAGE, LIKUIDITAS, PROFITABILITAS DAN UKURAN PERUSAHAAN TERHADAP PENGUNGKAPAN CORPORATE SOCIAL RESPONSIBILITY
}

\author{
Ida Ayu Putri Laksmidewi Purba ${ }^{1}$ \\ Made Reina Candradewi \\ Fakultas Ekonomi dan Bisnis Universitas Udayana (Unud), Bali, Indonesia \\ Email: putri.laksmidewi@yahoo.com
}

\begin{abstract}
ABSTRAK
Corporate Social Responsibility (CSR) merupakan tanggungjawab perusahaan tidak hanya terhadap pemiliknya atau pemegang saham saja tetapi juga terhadap para stakeholder yang terkait dan/atau terkena dampak dari keberadaan perusahaan. Tujuan penelitian ini untuk mengetahui pengaruh leverage, likuiditas, profitabilitas dan ukuran perusahaan terhadap kebijakan pengungkapan CSR pada perusahaan manufaktur yang terdaftar di Bursa Efek Indonesia. Populasi penelitian ini adalah perusahaan manufaktur yang terdaftar di Bursa Efek Indonesia selama periode 2014-2016. Data yang dikumpulkan dengan metode purposive sampling, diperoleh sebanyak 26 perusahaan yang menjadi sampel penelitian. Teknik analisis data menggunakan regresi linear berganda. Hasil analisis menunjukkan bahwa variabel leverage, likuiditas, profitabilitas dan ukuran perusahaan berpengaruh positif dan signifikan terhadap kebijakan CSR pada perusahaan manufakur di Bursa Efek Indonesia pada tahun $2014-2016$.
\end{abstract}

Kata kunci: Corporate Social Responsibility, leverage, likuiditas, profitabilitas dan ukuran perusahaan

\begin{abstract}
Corporate Social Responsibility (CSR) is the responsibility of the company not only to its owners or shareholders but also to stakeholders who are related and / or affected by the existence of the company. The purpose of this study is to determine the effect of leverage, liquidity, profitability and company size on CSR disclosure policies in manufacturing companies listed on the Indonesia Stock Exchange. The population of this research is manufacturing companies listed on the Indonesia Stock Exchange during the 2014-2016 period. Data collected by purposive sampling method, obtained as many as 26 companies that became the study sample. The data analysis technique uses multiple linear regression. The results of the analysis show that the variables of leverage, liquidity, profitability and size of the company have a positive and significant effect on CSR policies in manufacturing companies on the Indonesia Stock Exchange in 2014-2016.
\end{abstract}

Keywords: Corporate Social Responsibility, leverage, liquidity, profitability and company size 


\section{PENDAHULUAN}

Tanggung jawab sosial perusahaan atau yang biasa disebut Corporate Social Responsibility (CSR) saat ini berkembang sangat baik ditingkat regional maupuinternasional dan telah menjadi bagian yang sangat penting dalam bisnis. Semua perusahaan yang ingin tetap berkelanjutan serta memiliki keunggulan kompetitif harus menjadikan CSR sebagai bagian dari strategi bisnisnya (Dewi, 2015). Tujuan dari operasi perusahaan bukan hanya untuk mendapatkan laba sebesar - besarnya, namun kini juga memikirkan kesejahteraan masyarakat dan mulai menyadari arti penting dari menjaga lingkungan sekitar operasional perusahaan.

Corporate Social Responsibility (CSR) merupakan suatu program tanggung jawab perusahaan terhadap sosial dan lingkungan disekitar perusahaan. Konsep yang dikemukakan oleh John Elkington (1997), yaitu The Triple Bottom Line menyatakan agar perusahaan dapat menjaga kelangsungan hidupnya maka perusahaan harus memperhatikan 3P, yaitu Profit, Planet dan People.

Hasibuan dan Sedyono (2006:73) menyatakan pengungkapan CSR dilakukan perusahaan untuk dapat memenuhi kepentingan stakeholder dan menjamin keberlangsungan perusahaan jangka panjang, CSR dianggap dapat menegaskan brand differentiation perusahaan, sarana untuk memperoleh license of operate, baik dari pemerintah maupun masyarakat, serta sebagai strategy risk management perusahaan (Atmaja dan Wibowo, 2015). Di Indonesia, masih banyak kasus-kasus yang terjadi akibat kurangnya kesadaran perusahaan mengenai kegiatan pertanggung jawaban sosial, sehingga terjadi masalah terkait 
Ida Ayu Putri Laksmidewi Purba, Pengaruh Leverage,likuiditas...

kerusakan lingkungan maupun konflik yang berhubungan kesejahteraan karyawan. Adapun salah satu contoh perusahaan manufaktur PT. Toba Pulp Lestari pada tahun 2012 sempat menuai kritik akibat kasus pencemaran lingkungan oleh limbah pabrik yang mengakibatkan kerusakan pada tanah pertanian, habitat ikan di danau Toba terganggu, polusi udara yang disusul kasus pelanggaran HAM. Hal ini menyebabkan warga sekitar melakukan penolakan terhadap perusahaan tersebut (www.kompasiana.com). Beberapa perusahaan yang sempat mendapat sorotan tajam lainnya adalah kasus PT. Freeport Indonesia, TPST Boong di Bogor, PT. Newmont di Buyat dan PT. Lapindo Brantas (www.kompasiana.com). Dari contoh kasus tersebut dapat dijelaskan bahwa perusahaan besar cenderung menjadi sorotan penting terkait pertanggung jawaban sosial mereka baik terhadap lingkungan maupun kesejahteraan karyawan, maka dari itu muncul kesadaran dari tiap perusahaan untuk menerapkan Corporate Social Responsibility (CSR). Melalui CSR, perusahaan berusaha untuk menunjukkan bahwa perusahaan mampu bertanggung jawab dan mempunyai kepedulian terhadap lingkungan, kesejahtraan karyawan, dan masyarakat.

Intensitas pengungkapan Corporate Social Responsibility (CSR) dapat dipengaruhi oleh beberapa faktor antara lain leverage, likuiditas, profitabilitas, dan ukuran perusahaan. Rasio leverage adalah rasio untuk mengukur seberapa besar perusahaan dibiayai dengan utang (Fahmi, 2012:72). Perusahaan perlu mengkombinasikan pendanaannya antara modal sendiri dengan utang. Semakin tinggi leverage, besar kemungkinan perusahaan untuk melakukan pelanggaran terhadap kontrak utang, sehingga manajer akan melaporkan laba saat ini lebih 
tinggi dibandingkan laba masa depan (Scott, 2000) dalam Ardilla (2011). Dengan laba dilaporkan lebih tinggi akan mengurangi kemungkinan perusahaan melanggar perjanjian utang dan manajer akan memilih metode akuntansi yang akan memaksimalkan laba sekarang.

Menurut Belkaoui dan Karpik (1989) dalam Eddy (2005) keputusan untuk mengungkapkan informasi sosial akan mengikuti suatu pengeluaran untuk pengungkapan yang menurunkan pendapatan. Sesuai dengan teori agensi maka manajemen perusahaan dengan tingkat leverage yang tinggi akan mengurangi pengungkapan tanggung jawab sosial yang dibuatnya agar tidak menjadi sorotan dari para debtholders.

Anggriani (2006) menyatakan perusahaan dengan rasio leverage yang lebih tinggi akan mengungkapkan lebih banyak informasi, karena biaya keagenan perusahaan dengan struktur modal seperti itu lebih tinggi. Oleh karena perusahaan dengan rasio leverage yang tinggi memiliki kewajiban untuk melakukan ungkapan yang lebih luas dari pada perusahaan dengan rasio leverage yang rendah. Brigham dan Houston (2006:201) menyatakan bahwa seberapa jauh perusahaan menggunakan utang (financial leverage) akan memiliki implikasi penting, salah satunya adalah dengan memperoleh dana melalui hutang, para pemegang saham, dapat mempertahankan kendali mereka atas perusahaan tersebut dengan sekaligus membatasi investasi yang mereka berikan.

Hal ini terbukti dengan adanya penelitian yang dilakukan Suhaenah (2012) menyatakan bahwa leverage berpengaruh positif signifikan terhadap pengungkapan CSR, begitu pula dengan penelitian dari Natalylova (2012) 
Ida Ayu Putri Laksmidewi Purba, Pengaruh Leverage,likuiditas...

menemukan bahwa leverage yang diukur dari debt to equity ratio berpengaruh positif signifikan terhadap jumlah pengungkapan corporate social responsibility sedangkan penelitian Sari (2012) Ramadhaningsih dan Utama (2013) menunjukan leverage tidak berpengaruh signifikan terhadap pengungkapan CSR. Perbedaan hasil penelitian tersebut menjadikan alasan penelitian ini menggunakan variabel leverage karena ingin menguji kembali pengaruh leverage terhadap pengungkapan CSR. Selain leverage, masih ada variabel lainnya seperti likuiditas yang mempengaruhi CSR. Dimana perusahaan yang memiliki tingkat likuiditas tinggi merupakan gambaran keberhasilan perusahaan dalam membayar kewajiban - kewajiban jangka pendeknya tepat waktu. Likuiditas menunjukkan hubungan antara kas dan aset lancar lainnya dari sebuah perusahaan dengan liabilitas lancarnya.

Likuiditas merupakan suatu indikator mengenai kemampuan entitas untuk membayar semua liabilitas finansial jangka pendek pada saat jatuh tempo dengan menggunakan aset lancar yang tersedia (Kamil dan Herusetya, 2012). Likuiditas merupakan salah satu kinerja yang sering dijadikan tolak ukur investor dalam menilai perusahaan. Oleh karena itu ketika likuiditas yang dihasilkan tinggi, perusahaan akan cenderung melakukan pengungkapan CSR. Rahardjo (2006:110) menyatakan bahwa rasio likuiditas bertujuan menaksir kemampuan keuangan perusahaan dalam memenuhi kewajiban jangka pendek dan komitmen pembayaran keuangannya. Semakin tinggi angka rasio likuiditas, akan semakin baik bagi investor. Perusahaan yang diminati investor adalah perusahaan yang 
mempunyai rasio likuiditas yang cukup tinggi untuk standar perusahaan sejenisnya (Fahmi(2012:53).

Penelitian Widianingsih (2011) menjelaskan dalam penelitiannya bahwa likuiditas mempengaruhi signifikan pengungkapan (CSR). Sejalan dengan penelitian CSR (Rosyadi,2015) dan Widianingsih (2011) menyatakan bahwa likuiditas berpengaruh positif signifikan terhadap kelengkapan pengungkapan CSR. Bertolak belakang dengan Adhelia (2008), Prihastuti (2008), dan Badjuri (2011) menyatakan tidak berhasil menemukan pengaruh yang signifikan antara tingkat likuiditas dengan pengungkapan sosial (CSR).

Begitu pula dengan rasio profitabilitas merupakan rasio untuk menilai kemampuan perusahaan dalam mencari keuntungan atau laba dalam suatu periode tertentu. Rasio ini juga memberikan ukuran tingkat efektivitas menajemen suatu perusahaan yang ditunjukkan dari laba yang dihasilkan dari penjualan atau dari pendapatan investasi. Dikatakan perusahaan profitabilitasnya baik apabila mampu memenuhi target laba yang telah ditetapkan dengan menggunakan aktiva atau modal yang dimilikinya (Kasmir, 2015:114).

Sembiring (2005) menyaratakan bahwa profitabilitas yang tinggi memicu para stakeholder untuk meningkatkan kepentingan dan harapan mereka akan transparansi yang seharusnya dilakukan oleh perusahaan. Oleh karena itu, dapat dinyatakan bahwa semakin tinggi tingkat profitabilitas yang dihasilkan perusahaan maka pengungkapan CSR akan cenderung semakin besar.

Hal ini sejalan dengan penelitian yang dilakukan Rindawati (2015), Purba (2015), Setyono (2014), dan Budiman (2015) menunjukkan bahwa "profitabilitas berpengaruh 
Ida Ayu Putri Laksmidewi Purba, Pengaruh Leverage,likuiditas...

positif signifikan terhadap pengungkapan corporate social responsibility". Selain itu Fath (2016) menemukan adanya hubungan yang signifikan antara kinerja ekonomi (ROA) dengan pengungkapan indeks sosial dan lingkungan (Fath, 2016). Sedangkan hasil penelitian Kamil (2012) Mutia, Zuraida, \& Andriani (2011) Dewi dan Suaryana (2015)“"profitabilitas tidak berpengaruh terhadap pengungkapan corporate social responsibility".

Menurut Maiyarni, Susfayetti \& Erwati (2014) profitabilitas berpengaruh negatif signifikan terhadap pengungkapam CSR, sedangkan menurut Dewi dan Suaryana (2015) variabel profitabilitas tidak berpengaruh terhadap pengungkapan corporate social responsibility, karena skor untuk menghitung CSR tidak melibatkan besaran uangnya, sehingga skor yang tinggi belum tentu mengindikasikan bahwa kegiatan corporate social responsibility dalam jumlah nilai uang yang lebih besar. Dan juga variabel yang mempengaruhi ukuran perusahaan adalah suatu skala dimana dapat diklasifikasikan besar kecilnya perusahaan (Nugraha,2013). Pada umumnya perusahaan yang besar akan mengungkapkan lebih banyak informasi dibandingkan dengan perusahaan kecil. Perusahaan besar merupakan entitas yang paling banyak disorot oleh pasar. Sebagai wujud akuntabilitas publik, perusahaan akan mengungkapkan lebih banyak informasi sosial kepada stakeholders. Fahrizqi (2010) dan Sembiring (2015) menemukan adanya hubungan yang signifikan antara ukuran perusahaan dengan pengungkapan CSR, sementara Anggraini (2006) tidak menemukan bukti, bahwa besar kecilnya ukuran perusahaan mempengaruhi pengungkapan CSR. 
Ukuran perusahaan merupakan suatu skala yang berfungsi untuk mengklasifikasikan besar kecilnya suatu entitas. Secara umum, perusahaan besar akan mengungkapkan informasi sosial atau tanggung jawab sosial lebih banyak daripada perusahaan kecil (Nugraha,2013). Hal ini dapat dijelaskan secara teoritis bahwa perusahaan besar merupakan entitas bisnis yang tidak lepas dari risiko tekanan politis yang lebih besar dibandingkan perusahaan kecil (Sudarmadji dan Sularto (2007:54). Tekanan politis ialah tekanan untuk entitas bisnis yang banyak disoroti oleh masyarakat luas agar lebih mengungkapkan tanggung jawab sosial (CSR) atas aktivitas usahanya terhadap lingkungan sekitarnya. Bahwa dengan adanya pengungkapan aktivitas sosial yang lebih besar merupakan pengurangan biaya politis bagi perusahaan, sehingga perusahaan dalam jangka waktu panjang bisa terhindar dari biaya yang sangat besar akibat dari tuntutan masyarakat. Sembiring (2005) menyatakan perusahaan besar merupakan emiten yang banyak disoroti, pengungkapan yang lebih besar merupakan pengurangan biaya politis sebagai wujud tanggung jawab sosial perusahaan. Cowen et al. (1987) dalam Devina (2004) menyatakan perusahaan yang lebih besar terhadap masyarakat akan memiliki pemegang saham yang mungkin memperhatikan program sosial yang dibuat perusahaan dan laporan tahunan akan menyebarkan informasi tangung jawab sosial tersebut.

Beberapa penelitian yang berhasil membuktikan hubungan positif signifikan antara variabel ukuran perusahaan dan luas pengungkapan tanggung jawab sosial antara lain dilakukan oleh Eddy (2005), Purwanto (2011) serta Rahma (2010). Tetapi tidak semua penelitian mendukung hubungan antara ukuran perusahaan 
Ida Ayu Putri Laksmidewi Purba, Pengaruh Leverage,likuiditas...

dengan luas pengungkapan tanggung jawab sosial perusahaan. Ada juga penelitian yang tidak berhasil menunjukan hubungan positif antar kedua variabel tersebut, yaitu penelitian yang dilakukan oleh Achmad (2007), Oktariani (2014) dan Mimba (2014).

Manajemen mempunyai informasi yang lebih banyak mengenai perusahaan dan prospek perusahaan dimasa mendatang dibandingkan dengan pemilik perusahaan, manajemen berkewajiban memberikan laporan mengenai kondisi perusahaan kepada pemilik perusahaan dalam bentuk laporan keuangan. Dipilihnya perusahaan manufaktur sebagai sampel pada penelitian ini dikarenakan dalam aktivitasnya perusahaan manufaktur memerlukan manajemen dengan tingkat efektifitas yang tinggi yang ditunjukkan oleh laba yang dihasilkan. Selain itu, dipilihnya perusahaan manufaktur dikarenakan perusahaan manufaktur mempunyai dampak lebih besar terhadap lingkungan disekitarnya yang merupakan aspek dari pengungkapan CSR. Penelitian ini menggunakan perusahaan manufaktur sebagai sampel karena perusahaan manufaktur memiliki market capitalize yang berarti harga saham perusahaan tersebut cukup tinggi. Pencapaian tersebut disebabkan banyak calon investor, kreditur, dan pemasok tertarik menjalin kerjasama dengan perusahaan manufaktur.

Penelitian ini menggunakan variabel dependen pengungkapan CSR untuk diteliti apakah variabel tersebut dipengaruhi oleh leverage, likuiditas, profitabilitas dan ukuran perusahaan terhadap pengungkapan CSR pada perusahaan yang terdaftar di Bursa Efek Indonesia (BEI). 
Pendekatan stakeholders muncul pada pertengahan tahun 1980. Pendekatan stakeholders berusaha memberikan kesadaran bahwa bisnis harus dijalankan sedemikian rupa agar hak dan kepentingan semua pihak terkait yang berkepentingan dengan suatu kegiatan bisnis dijamin, diperhatikan, dan dihargai (Dewi, 2010:53). Tujuan manajemen stakeholders adalah merancang metode untuk mengelola berbagai kelompok dan hubungan yang dihasilkan dengan cara yang sangat strategis (Freeman dan McVea, 2001).

Pihak yang berkepentingan (stakeholders) adalah individu atau kelompok yang dapat dipengaruhi atau mempengaruhi tindakan, keputusan, kebijakan, praktek, dan tujuan organisasi bisnis (Dewi, 2010:53). Kelangsungan hidup perusahaan tergantung pada dukungan stakeholders dan dukungan tersebut harus dicari sehingga aktivitas perusahaan adalah untuk mencari dukungan tersebut. Pengungkapan sosial dianggap sebagai bagian dari dialog antara perusahaan dengan stakeholdersnya (Gray et al., 1995).

Perusahaan harus bisa menjaga hubungan dengan stakeholders terutama stakeholders yang mempunyai power terhadap ketersediaan sumber daya yang akan digunakan untuk aktivitas operasional perusahaan, misalnya tenaga kerja, pasar atas produk perusahaan dan lain-lain (Ghozali dan Chariri, 2007). Salah satu strategi untuk menjaga hubungan dengan para stakeholders perusahaan adalah dengan melaksanakan CSR, dengan pelaksanaan CSR diharapkan keinginan dari stakeholders dapat terakomodasi sehingga akan menghasilkan hubungan yang harmonis antara perusahaan dengan stakeholdersnya. Hubungan 
Ida Ayu Putri Laksmidewi Purba, Pengaruh Leverage,likuiditas...

yang harmonis akan berakibat pada perusahaan dapat mencapai keberlanjutan atau kelestarian perusahaannya (sustainability).

Legitimasi merupakan keadaan psikologis keberpihakan orang dan kelompok orang yang sangat peka terhadap gejala lingkungan sekitar baik fisik maupun nonfisik (Hadi, 2011). Deegan dan Tobin (2002) menjabarkan bahwa legitimasi dapat diperolehmanakala terdapat kesesuaian antara keberadaan perusahaan tidak mengganggu atau sesuai dengan eksistensi sistem nilai yang ada dalam masyarakat dan lingkungan. Ketika terjadi pergeseran yang menuju ketidaksesuaian, maka pada saat itu legitimasi perusahaan terancam. Dari uraian di atas dapat disimpulkan bahwa legitimasi perusahaan dimata stakeholder merupakan faktor signifikan untuk mendukung citra dan reputasi perusahaan dimata stakeholder (Hadi, 2011). Dengan demikian, maka pengungkapan informasi CSR merupakan investasi jangka panjang dan memiliki manfaat dalam meningkatkan image dan legitimasi, sehingga dapat dijadikan sebagai basis konstruksi strategi perusahaan.

CSR adalah suatu konsep yang bermaterikan tanggung jawab sosial dan lingkungan oleh perusahaan kepada masyarakat luas, khususnya di wilayah perusahaan tersebut beroperasi (Dewi, 2010:79). CSR merupakan sebuah gagasan yang menjadikan perusahaan tidak lagi dihadapkan pada tanggung jawab yang berpijak pada nilai perusahaan yang di refleksikan dalam kondisi keuangannya saja. Kesadaran atas pentingnya CSR dilandasi pemikiran bahwa perusahaan tidak hanya mempunyai kewajiban ekonomi dan legal kepada pemegang saham (shareholder) melainkan juga kewajiban terhadap stakeholder yang terkait 
dan/atau terkena dampak dari keberadaan perusahaan. Hal ini sesuai dengan teori stakeholders yang menyatakan bahwa perusahaan bukanlah entitas yang hanya beroperasi untuk kepentingannya sendiri namun harus memberikan manfaat bagi stakeholdersnya (Wibisono, 2007).

Gray et al. (1995) juga menyatakan bahwa kelangsungan hidup perusahaan tergantung pada dukungan stakeholders dan dukungan tersebut harus dicari sehingga aktivitas perusahaan adalah untuk mencari dukungan tersebut dan CSR merupakan bagian dari dialog antara perusahaan dan stakeholdersnya. Teori stakeholders adalah teori yang menggambarkan tanggung jawab perusahaan. Perusahaan harus menjaga hubungan dengan stakeholdersnya dengan mengakomodasi keinginan dan kebutuhan stakeholdersnya, terutama stakeholders yang mempunyai power terhadap ketersediaan sumber daya yang digunakan untuk aktivitas operasional perusahaan, misalnya tenaga kerja, pasar atas produk perusahaan dan lain-lain (Ghozali dan Chariri, 2007).

Salah satu strategi untuk menjaga hubungan dengan para stakeholders perusahaan adalah dengan melaksanakan CSR, dengan pelaksanaan CSR diharapkan keinginan dari stakeholders dapat terakomodasi sehingga akan menghasilkan hubungan yang harmonis antara perusahaan dengan stakeholdersnya. Hubungan yang harmonis mengakibatkan perusahaan mencapai keberlanjutan atau kelestarian (sustainability).

Risiko kredit didefinisikan sebagai risiko kerugian sehubungan dengan pihak peminjam (counterparty) tidak dapat atau tidak mau memenuhi kewajiban untuk membayar kembali dana yang dipinjamnya secara penuh pada saat jatuh tempo 
atau sesudahnya (Idroes, 2011: 23). Menurut Veitzhal dkk. (2007: 477) Kredit bermasalah adalah kredit dimana pembayaran kembalinya dalam bahaya, terutama apabila sumber - sumber pembayaran kembali yang diharapkan diperkirakan tidak cukup untuk membayar kembali kredit sehingga belum memenuhi target yang diinginkan oleh bank. Diantara operasional bank yang terkait dengan sejumlah aset yang menghasilkan pendapat ditemukan bahwa resiko kredit menjadi penentu dari kinerja bank (Gizaw et al., 2015).

Penelitian ini mengidentifikasi hal-hal yang berkaitan dengan pelaporan sosial perusahaan berdasarkan standar Global Reporting Initiative (GRI). Global Reporting Initiative adalah sebuah jaringan berbasis organisasi yang telah mempelopori perkembangan dunia, paling banyak menggunakan kerangka laporan keberlanjutan dan berkomitmen untuk terus-menerus melakukan perbaikan dan penerapan di seluruh dunia (www.globalreporting.org). Indikatorindikator yang terdapat di dalam GRI yang digunakan dalam penelitian yaitu. Indikator Kinerja Ekonomi (economic performance indicator), Indikator Kinerja Lingkungan (environment performance indicator), Indikator Kinerja Tenaga Kerja (labor practices performance indicator), Indikator Kinerja Hak Asasi Manusia (human rights performance indicator), Indikator Kinerja Sosial (social performance indicator), Indikator Kinerja Produk (product responsibility performance indicator).

Indikator yang digunakan dalam penelitian ini berdasarkan Global Reporting Initiative Generation 4 (GRI G4), yaitu indikator kinerja ekonomi, lingkungan dan sosial. Indikator kinerja sosial mencakup empat indikator yang terdiri dari: tenaga 
kerja, hak asasi manusia, sosial/kemasyarakatan, dan produk. East-West Management Institute and PFS program, (2004) dalam Harmoni (2008) mengklasifikasikan pengungkapan CSR kedalam tiga pilar dasar yang disebut Index Publisitas.

Menurut Sjahrial (2009:147), leverage adalah penggunaan aktiva dan sumber dana oleh perusahaan yang memiliki biaya tetap (beban tetap) berarti sumber dana yang berasal dari pinjaman karena memiliki bunga sebagai beban tetap dengan maksud agar meningkatkan keuntungan potensial pemegang saham. Rasio leverage merupakan proporsi total hutang terhadap rata-rata ekuitas pemegang saham. Rasio tersebut digunakan untuk mengukur seberapa jauh perusahaan dibiayai oleh dana pinjaman (Wiagustini, 2010:77).

$D E R$ digunakan untuk mengukur tingkat penggunaan hutang terhadap total shareholder's equity yang dimiliki perusahaan. Rasio ini menunjukkan pentingnya sumber modal pinjaman dan tingkat keamanan yang dimiliki kreditur Sembiring (2005).

Likuiditas adalah kemampuan suatu perusahaan untuk memenuhi kewajiban keuangannya yang harus dipenuhi, atau kemampuan perusahaan untuk memenuhi kewajiban keuangan pada saat ditagih. Perusahaan yang mampu memenuhi kewajiban keuangannya tepat pada waktunya berarti perusahaan tersebut dalam keadaan likuid, dan perusahaan dikatakan mampu memenuhi kewajiban keuangan tepat pada waktunya apabila perusahaan tersebut mempunyai alat pembayaran ataupun aktiva lancar yang lebih besar dari hutang lancarnya atau hutang jangka pendek. Sebaliknya jika perusahaan tidak dapat segera 
Ida Ayu Putri Laksmidewi Purba, Pengaruh Leverage,likuiditas...

memenuhi kewajiban keuangannya pada saat ditagih, berarti perusahaan tersebut dalam keadaan illikuid Munawir (2014).

Kasmir (2008) menyatakan likuiditas atau sering disebut modal kerja digunakan untuk mengukur seberapa likuidnya suatu perusahaan. Menurut Harahap (2009) likuiditas menggambarkan kemampuan perusahaan menyelesaikan kewajiban jangka pendeknya. Likuiditas dapat dihitung melalui sumber informasi tentang modal kerja yaitu pos-pos aktiva lancar dan hutang lancar. Pengukuran likuiditas yang digunakan terdiri dari rasio lancar (current ratio), rasio cepat (quick ratio), rasio kas (aktiva lancar), rasio kas atas utang lancar, rasio aktiva lancar dan total aktiva, serta aktiva lancar dan total utang.

Current ratio menunjukkan sejauhmana aktiva lancar menutupi kewajibankewajiban lancar. Semakin besar perbandingan aktiva lancar dan kewajiban lancar semakin tinggi kemampuan perusahaan menutupi kewajiban jangka pendeknya. Current ratio yang rendah biasanya dianggap menunjukkan terjadinya masalah dalam likuidasi, sebaliknya current ratio yang terlalu tinggi juga kurang bagus, karena menunjukkan banyaknya dana menganggur yang pada akhirnya dapat mengurangi kemampulabaan perusahaan (Sawir, 2009:10)

Menurut Heinze dalam Untari (2010), Profitabilitas merupakan faktor yang memberikan kebebasan dan fleksibilitas kepada manajemen untuk mengungkapkan pertanggungjawaban sosial kepada pemegang saham. Dari batasan ini kita akan bias mengukur profitabilitas perusahaan apabila kita tahu berapa laba perusahaan yang diperoleh pada suatu periode tertentu dan berapa modal sendiri yang digunakan atau berapa jumlah nilai investasi yang digunakan 
untuk memperoleh laba tersebut (Wiagustini, 2010:77). Nikolis (2013) rasio profitabilitas memiliki beberapa macam jenis meliputi Return on Assets (ROA), Return on Equity (ROE), Profit Margin dan Earning per Share (EPS).

Rasio profitabilitas mampu mencerminkan keberhasilan perusahaan dalam menghasilkan keuntungan. Semakin besar keuntungan yang didapatkan semakin besar kemampuan perusahaan membayarkan dividennya. Profitabilitas dapat menjadi pertimbangan bagi investor dalam berinvestasi.

Penelitian ini menggunakan ROA sebagai ukuran profitabilitas perusahaan, ROA merupakan rasio antara laba bersih terhadap total aktiva. Semakin besar ROA menunjukkan profitabilitas perusahaan semakin baik. ROA merupakan gambaran dari kondisi perusahaan saat ini dan bisa digunakan sebagi acuan untuk memprediksi masa depan perusahaan.

Ukuran perusahaan merupakan variabel yang banyak digunakan untuk menjelaskan pengungkapan sosial yang dilakukan perusahaan dalam laporan tahunan yang dibuat. Secara umum perusahaan besar akan mengungkapkan informasi lebih banyak daripada perusahaan kecil. Hal ini karena perusahaan besar akan menghadapi risiko politis yang lebih besar dibanding perusahaan kecil.

Secara teoritis perusahaan besar tidak akan lepas dari tekanan politis, yaitu tekanan untuk melakukan pertanggungjawaban sosial. Pengungkapan sosial yang lebih besar merupakan pengurangan biaya politis bagi perusahaan (Adhi, 2010). Penelitian variabel ukuran perusahaan diukur dengan logaritma natural total asset (Nur Marzully dan Priantinah Denies, 2012). 


\section{Kerangka Konseptual}

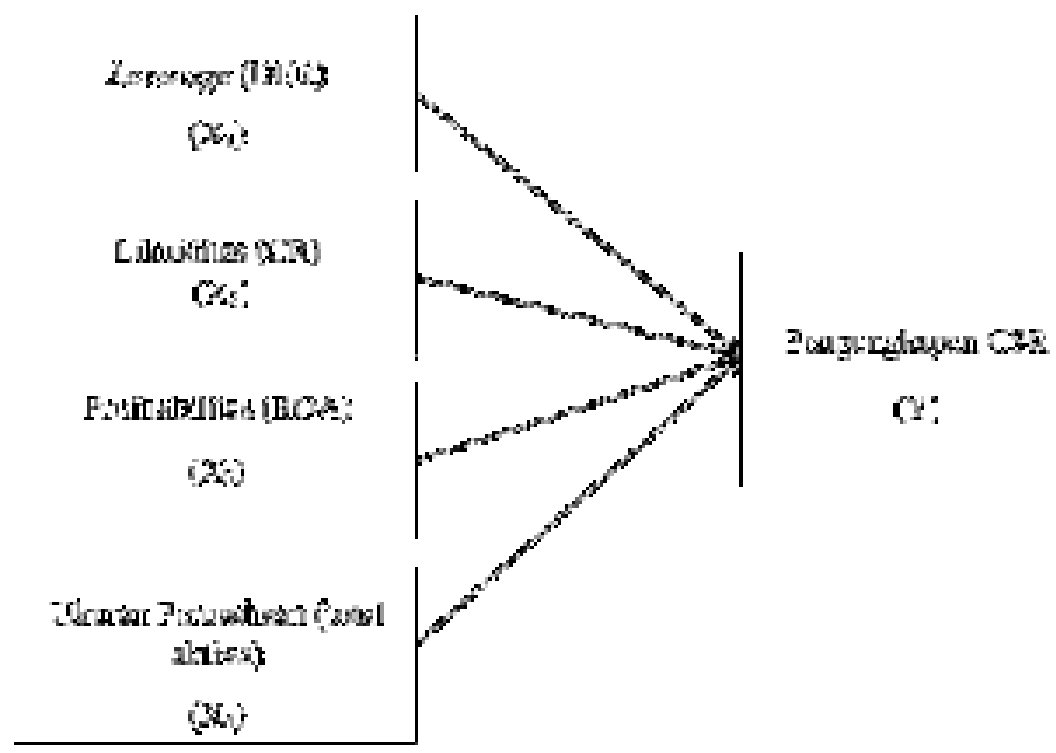

Gambar 2.1 Kerangka Konseptual Penelitian

Keterangan:

DER = Debt to Equity Ratio

$\mathrm{CR}=$ Current Ratio

ROA = Return On Assets

CSR = Corporate Social Responsibility

\section{HASIL DAN PEMBAHASAN}

Berdasarkan hasil olahan data dengan program SPSS diperoleh data statistik deskriptif yang memberikan informasi mengenai nilai minimum, nilai maksimum, rata-rata variabel penelitian dan nilai standar deviasi dari masing masing variabel. Hasil statistik deskriptif disajikan pada Tabel 1.

Berdasarkan Tabel 1. diketahui bahwa terdapat lima variabel penelitian yaitu, CSR, leverage, likuiditas, profitabilitas, dan ukuran perusahaan. Jumlah data pengamatan keseluruhan juga dapat dilihat pada tabel yaitu sebanyak 78 pengamatan. Penjelasan mengenai hasil perhitungan statistik deskriptif diuraikan 
sebagai berikut. Corporate Social Responsibility. CSR dalam penelitian ini diproksikan dengan $\mathrm{n}(\mathrm{CSR})$.

Tabel 1.

Statistik Deskriptif Variabel Penelitian

Std.

\begin{tabular}{|c|c|c|c|c|c|}
\hline & & Minimum & Maximum & Mean & Deviation \\
\hline CSR & 78 & 46,67 & 100,00 & 81,0250 & 12,11132 \\
\hline Leverage & 78 & $-6,93$ & 4,87 & ,9795 & 1,65850 \\
\hline
\end{tabular}

$\begin{array}{lrrrrr}\text { Likuiditas } & 78 & 36,05 & 46498,44 & 875,3122 & 5244,87195 \\ \text { Profitabilitas } & 78 & -16,11 & 20,78 & 3,6285 & 6,50991 \\ \text { Ukuran Perusahaan } & 78 & 25,64 & 37,94 & 28,6698 & 1,91842\end{array}$

Sumber: data diolah,

Berdasarkan hasil statistik deskriptif yang ditunjukkan pada Tabel 1. dengan jumlah data $(\mathrm{N})$ sebanyak 26 dengan periode waktu tiga tahun (20142016) menunjukkan nilai rata-rata (mean) 81,0250 dengan standar deviasi sebesar 12,11132 Nilai terendah (minimum) dari CSR n(CSR) 0.47 dimiliki oleh Impack Pratama Industry Tbk ditahun 2014, sedangkan nilai tertinggi (maksimum) dari CSR $\mathrm{n}(\mathrm{CSR})$ adalah 1 dimiliki oleh Semen Indonesia (Persero) Tbk ditahun 2014, 2015 dan 2016. Berdasarkan hasil statistik deskriptif yang ditunjukkan pada Tabel 1. dengan jumlah data $(\mathrm{N})$ sebanyak 26 dengan periode waktu tiga tahun (2014-2016) menunjukkan nilai rata-rata (mean) 0.9795 dengan standar deviasi sebesar 1,6585. Nilai terendah (minimum) dari leverage -6.93 dimiliki oleh SLJ Global Tbk.ditahun 2016, sedangkan nilai tertinggi (maksimum) dari perputaran modal kerja adalah 4.87 dimiliki oleh Saranacentral Bajatama Tbk ditahun 2015. Likuiditas dalam penelitian ini 
Ida Ayu Putri Laksmidewi Purba, Pengaruh Leverage,likuiditas...

diproksikan dengan current ratio (CR). Berdasarkan hasil statistik deskriptif yang ditunjukkan pada Tabel 1. dengan jumlah data $(\mathrm{N})$ sebanyak 26 dengan periode waktu tiga tahun (2014-2016) menunjukkan nilai rata-rata (mean) 875.3122 dengan standar deviasi sebesar 5244,87195. Nilai terendah (minimum) dari likuiditas 36.05 dimiliki oleh Kertas Basuki Rachmat Indonesia Tbk ditahun 2016, sedangkan nilai tertinggi (maksimum) dari likuiditas adalah 46498.44 dimiliki oleh Jaya Pari Steel Tbk ditahun 2014. Profitabilitas dalam penelitian ini diproksikan dengan return on asset (ROA). Berdasarkan hasil statistik deskriptif yang ditunjukkan pada Tabel 1. dengan jumlah data $(\mathrm{N})$ sebanyak 26 dengan periode waktu tiga tahun (2014-2016) menunjukkan nilai rata-rata (mean) 3.6285 dengan standar deviasi sebesar 6,50991. Nilai terendah (minimum) dari profitabilitas (ROA) -16.11 dimiliki oleh Sierad Produce Tbk ditahun 2015, sedangkan nilai tertinggi (maksimum) dari profitabilitas (ROA) adalah 20.78 dimiliki oleh Arwana Citramulia Tbk ditahun 2014. Berdasarkan hasil statistik deskriptif yang ditunjukkan pada Tabel 1. dengan jumlah data $(\mathrm{N})$ sebanyak 26 dengan periode waktu tiga tahun (2014-2016) menunjukkan nilai rata-rata (mean) 28.6698 dengan standar deviasi sebesar 1,91842. Nilai terendah (minimum) dari ukuran perusahaan 25.64 dimiliki oleh Alakasa Industrindo Tbk ditahun 2016, sedangkan nilai tertinggi (maksimum) dari ukuran perusahaan adalah 37.94 dimiliki oleh Indocement Tunggal Prakarsa Tbk ditahun 2016. Analisis regresi linier berganda digunakan untuk mengetahui arah dan besarnya pengaruh leverage, likuiditas, profitabilitas dan ukuran perusahaan terhadap pengungkapan CSR yang terdaftar di Bursa Efek Indonesia. Untuk 
mempermudah pengolahan data digunakan program SPSS. Hasil analisis regresi linear berganda disajikan pada Tabel 2.

Tabel 2.

Hasil Analisis Regresi Linear

\begin{tabular}{|c|c|c|c|c|c|}
\hline \multirow{2}{*}{ Model } & \multicolumn{2}{|c|}{$\begin{array}{l}\text { Unstandardized } \\
\text { Coefficients }\end{array}$} & \multirow{2}{*}{$\begin{array}{l}\text { Standardized } \\
\text { Coefficients }\end{array}$} & \multirow[b]{2}{*}{$\mathrm{t}$} & \multirow[b]{2}{*}{ sig } \\
\hline & B & Std. Error & & & \\
\hline 1 (Contant) & 8,344 & 1,470 & & 5,676 & 0,000 \\
\hline Leverage & 1,258 & 0,271 & 0,318 & 4,635 & 0,000 \\
\hline Likuiditas & 1,112 & 0,282 & 0,287 & 3,945 & 0,000 \\
\hline Profitabilitas & 0,844 & 0,236 & 0,264 & 3,580 & 0,000 \\
\hline $\begin{array}{l}\text { Ukuran } \\
\text { Perusahaan }\end{array}$ & 1,307 & 0,221 & 0,410 & 5,914 & 0,000 \\
\hline
\end{tabular}

Berdasarkan Tabel 2. diatas dapat dirumuskan persamaan regresi linier berganda sebagai berikut :

$$
\mathrm{Y}=8,344+0,318\left(\mathrm{X}_{1}\right)+0,287\left(\mathrm{X}_{2}\right)+0,264\left(\mathrm{X}_{3}\right)+0,410\left(\mathrm{X}_{4}\right)
$$

Keterangan :

$$
\begin{array}{lll}
\mathrm{Y} & = & \text { CSR } \\
\mathrm{X}_{1} & = & \text { Leverage } \\
\mathrm{X}_{2} & = & \text { Likuiditas } \\
\mathrm{X}_{3}= & \text { Profitabilitas } \\
\mathrm{X}_{4}= & \text { Ukuran Perusahaan }
\end{array}
$$

Hasil penelitian ini menunjukkan bahwa leverage berpengaruh positif dan signifikan terhadap pengungkapan CSR pada perusahaan manufaktur di BEI periode 2014- 2016. Jadi hasil penelitian ini mendukung hipotesis yang pertama yaitu Leverage berpengaruh positif dan signifikan terhadap pengungkapan CSR perusahaan manufaktur di BEI periode 2014-2016. Semakin 
tinggi tingkat leverage semakin efektif penggunaan modal kerja dan semakin cepat modal kerja berputar semakin besar keuntungan yang didapatkan untuk meningkatkan pengungkapan CSR perusahaan. Hasil penelitian ini mendukung oleh hasil penelitian sebelumnya yang dilakukan oleh Suhaenah (2012) , Natalylova (2012), yang mendapatkan hasil bahwa Leverage berpengaruh positif dan signifikan terhadap pengungkapan CSR perusahaan.

Hasil penelitian ini menunjukkan bahwa likuiditas yang diproksikan dengan CR berpengaruh positif dan signifikan terhadap pengungkapan CSR pada perusahaan manufaktur di BEI periode 2014-2016. Jadi hasil penelitian ini mendukung hipotesis yang kedua yaitu likuiditas berpengaruh positif dan signifikan terhadap pengungkapan CSR perusahaan manufaktur di BEI periode 2014-2016. Semakin tinggi current ratio berarti semakin besar kemampuan perusahaan untuk memenuhi kewajiban jangka pendek. Nilai current ratio yang tinggi menunjukkan bahwa perusahaan melakukan penempatan dana yang besar pada sisi aktiva lancar. Jadi hal ini tidak baik bagi pengungkapan CSR perusahaan karena aktiva lancar menghasilkan return yang lebih rendah dibandingkan dengan aktiva tetap. Hasil penelitian ini didukung oleh hasil penelitian sebelumnya yang dilakukan oleh Khatik and Veryhese (2015) likuiditas (current ratio) berpengaruh positif dan signifikan terhadap pengungkapan CSR perusahaan.

Hasil penelitian ini menunjukkan bahwa profitabilitas yang diproksikan dengan ROA berpengaruh positif dan signifikan terhadap Pengungkapan CSR yang diproksikan dengan CSR pada perusahaan manufaktur di BEI periode 2014- 
2016. Jadi hasil penelitian ini mendukung hipotesis yang ketiga yaitu profitabilitas berpengaruh positif dan signifikan terhadap Pengungkapan CSR perusahaan manufaktur di BEI periode 2014-2016. Hasil penelitian ini mendukung oleh hasil penelitian sebelumnya yang dilakukan oleh Khatik and Veryhese (2015) profitabilitas (ROA) berpengaruh positif dan signifikan terhadap profitabilitas perusahaan.

Hasil penelitian ini menunjukkan bahwa ukuran perusahaan berpengaruh positif dan signifikan terhadap Pengungkapan CSR pada perusahaan manufaktur di BEI periode 2014-2016. Jadi hasil penelitian ini mendukung hipotesis yang kedua yaitu ukuran perusahaan berpengaruh positif dan signifikan terhadap profitabilitas perusahaan tekstil dan garmen di BEI periode 2014-2016. Ukuran perusahaan menggambarkan besar kecilnya suatu perusahaan. Penentuan besar kecilnya skala perusahaan dapat ditentukan berdasarkan total penjualan, rata-rata tingkat penjualan, total aktiva dan rata-rata total aktiva. Perusahaan yang besar memiliki total asset yang besar, sehingga perusahaan mampu mengoptimalkan kinerja perusahaan, dengan aset yang dimilikinya. Hasil penelitian ini didukung oleh hasil penelitian sebelumnya yang dilakukan oleh Yazdanfar and Ohman (2014), Ehi-Oshio et al. (2013), Gill et al. (2011), Abu Tapanjeh (2016), Yazdanfar Darush (2013) serta Niresh and Velnampy (2014) yang menunjukkan bahwa ukuran perusahaan berpengaruh positif dan signifikan terhadap Pengungkapan CSR perusahaan.

Penelitian ini membahas mengenai pengaruh variabel leverage, likuiditas, profitabilitas, dan ukuran perusahaan dan likuiditas terhadap Pengungkapan CSR 
pada perusahaan manufaktur di BEI periode 2014-2016. Implikasi dari penelitian ini yaitu. Pertama variabel leverage memiliki pengaruh positif signifikan terhadap Pengungkapan CSR atau $\mathrm{n}(\mathrm{CSR})$ pada perusahaan manufaktur. leverage adalah penggunaan aktiva dan sumber dana oleh perusahaan yang memiliki biaya tetap (beban tetap) berarti sumber dana yang berasal dari pinjaman karena memiliki bunga sebagai beban tetap dengan maksud agar meningkatkan keuntungan potensial pemegang saham. Rasio leverage merupakan proporsi total hutang terhadap rata-rata ekuitas pemegang saham. Jadi leverage yang baik dan cukup akan menunjang Pengungkapan CSR perusahaan.

Variabel kedua adalah Likuiditas yang diproksikan dengan CR memiliki pengaruh positif signifikan terhadap Pengungkapan CSR pada perusahaan manufaktur. Likuiditas menunjukan kemampuan untuk membayar kewajiban finansial jangka pendek tepat pada waktunya, likuiditas perusahaan ditunjukan oleh besar kecilnya aktiva lancar. Current ratio atau rasio lancar adalah nilai yang menunjukkan ketersediaan aset lancar untuk memenuhi kewajiban lancar, dengan demikian semakin besar nilai CR maka semakin besar pengungkapan CSR. Nilai CR yang tinggi menunjukkan bahwa perusahaan melakukan penempatan dana yang besar pada sisi aktiva lancar.

Variabel ketiga adalah Profitabilitas memiliki pengaruh positif dan signifikan terhadap Pengungkapan CSR pada perusahaan manufaktur. Profitabilitas menggambarkan besar kecilnya tingkat laba. Penentuan besar kecilnya skala perusahaan dapat ditentukan berdasarkan total penjualan, ratarata tingkat penjualan, total aktiva dan rata-rata total aktiva. Perusahaan yang 
besar memiliki total asset yang besar, sehingga perusahaan mampu mengoptimalkan kineja perusahaan, dengan aset yang dimilikinya. Oleh sebab itu profitabilitas merupakan salah satu faktor yang menentukan kemampuan perusahaan menghasilkan laba perusahaan untuk melaksanakan kegiatan CSR.

Variabel keempat adalah Ukuran Perusahaan memiliki pengaruh positif dan signifikan terhadap Pengungkapan CSR pada manufaktur. Ukuran perusahaan menggambarkan besar kecilnya suatu perusahaan. Penentuan besar kecilnya skala perusahaan dapat ditentukan berdasarkan total penjualan, rata-rata tingkat penjualan, total aktiva dan rata-rata total aktiva. Perusahaan yang besar memiliki total asset yang besar, sehingga perusahaan mampu mengoptimalkan kineja perusahaan, dengan aset yang dimilikinya. Oleh sebab itu ukuran perusahaan mempunyai pengaruh yang lebih tinggi pada kelompok perusahaan dengan tingkat pengungkapan yang luas bila dibandingkan dengan kelompok perusahaan dengan tingkat pengungkapan yang sedikit.

\section{SIMPULAN}

Penelitian ini dilakukan untuk menguji variabel leverage, likuiditas, profitabilitas dan ukuran perusahaan yang dapat mempengaruhi pengungkapan CSR. Indeks pengungkapan CSR digunakan untuk menentukan pengungkapan CSR, perusahaan yang dijadikan sampel sebanyak 26 perusahaan selama periode tahun 2014 - 2016 dan dapat ditarik kesimpulan sebagai berikut. Leverage berpengaruh positif signifikan terhadap pengungkapan CSR pada perusahaan manufaktur yang terdaftar di Bursa Efek Indonesia periode 2014-2016. Likuiditas berpengaruh positif signifikan terhadap pengungkapan CSR 
Ida Ayu Putri Laksmidewi Purba, Pengaruh Leverage,likuiditas...

pada perusahaan Manufaktur yang terdaftar di Bursa Efek Indonesia periode 20142016. Ukuran Perusahaan berpengaruh positif signifikan terhadap pengungkapan CSR pada perusahaan Manufaktur yang terdaftar di Bursa Efek Indonesia periode 2014-2016. ,Ukuran Perusahaan berpengaruh positif signifikan terhadap pengungkapan CSR pada perusahaan Manufaktur yang terdaftar di Bursa Efek Indonesia periode 2014-2016.

Berdasarkan simpulan dan analisis yang telah dilakukan, maka saran yang dapat dikemukakan sebagai berikut. Bagi pihak perusahaan Dengan melaksanakan program CSR , maka sebaiknya perusahaan harus dapat meningkatkan pengelolaan manajemennya dalam mengambil keputusan, sehingga perusahaan sebaiknya tetap melaksanakan program CSR secara kontinyu. Karena dengan melaksanakan program tersebut perusahaan akan memperoleh pengakuan yang lebih oleh masyarakat.

Bagi peneliti selanjutnya. Pada peneliti selanjutnya disarankan agar penelitian selanjutnya hendaknya menambah rentang waktu penelitian dengan mengambil periode waktu yang lebih panjang. Menambahkan beberapa variabel lain sebagai faktor yang dapat mempengaruhi pengungkapan Corporate Social Responsibility (CSR), seperti ukuran dewan komisaris, kinerja lingkungan dan kinerja manejerial. Selain data sekunder yang menggunakan data lain, seperti kuisioner ataupun interview keperusahaan atau insitusi pemerintah untuk mengetahui informasi lebih lengkap mengenai pengungkapan Corporate Social Responsibility (CSR).

\section{REFERENSI}


Achmad Zaenuddin. 2007. Faktor-Faktor Yang Berpengaruh Terhadap Praktek Pengungkapan Sosial Dan Lingkungan Pada Perusahaan Manufaktur Go Publik. Tesis. Universitas Diponegoro.

Adhelia, Hexa. 2008. Analisis Faktor-Faktor yang Mempengaruhi Kelengkapan Pengungkapan Sosial dalam Laporan Tahunan Perusahaan (Studi pada Perusahaan High Profile yang Terdaftar di BEI). Fakultas Ekonomi Universitas Brawijaya. Malang.

Adhi, 2010, Analisis Pengaruh Kinerja Keuangan Terhadap Tanggung Jawab Sosial Perusahaan (Corporate SocialResponsibility) (Studi Pada Bank Di Indonesia Periode Tahun 2007- 2008), Skripsi, Fakultas Ekonomi Universitas Diponegoro Semarang.

Aini, Budiman, \& Wijayanti. 2014. Kepatuhan Wajib Pajak Badan di Perusahaan Manufaktur di Semarang dalam Perspektif InfestasiJurnal Bisnis dan Akuntansi Vol.10, No.1, 2014.

Anggraini, Fr. Reni Retno. 2006. Pengungkapan Informasi Sosial dan FaktorFaktor yang Mempengaruhi Pengungkapan Informasi Sosial dalam Laporan Keuangan Tahunan (Studi Empiris pada Perusahaan- Perusahaan yang Terdaftar di Bursa Efek Jakarta). Simposium Nasional Akuntansi 9, Padang.

Atmaja, Ayub Arisetya dan Wibowo, Alexander Jatmiko. 2015. Pengaruh KepemilikanAsing dan Corporate Social Responsibility Terhadap Kinerja Perusahaan yang Terdaftar dalam Indeks Sri- Kehati Tahun 2009 - 2013. Skripsi Sarjana Jurusan Manajemen Fakultas Ekonomi Universitas Atma Jaya, Yogyakarta.

Badjuri, Achmad. 2011. Faktor-faktor Fundamental, Mekanisme Corporate Governance, Pengungkapan Corporate Social Responsibility (CSR) Perusahaan Manufaktur dan Sumber Daya Alam di Indonesia. Dinamika Keuangan dan Perbankan. Universitas Stikubank.

Beasley, M. dan S. Salterio. 2001. The Relationship Between Board Characteristics and Voluntary Improvements in Audit Committee CompositionandExperience.http://papers.ssrn.com/sol3/papers.cfm?abstr act $i d=27$ 2590\&. Diakses tanggal 25Juli 2014.

Belkaoui, A. dan P. G. Karpik. 1989. Determinants of the Corporate Decision to Disclose Social Information. Accounting, Auditing and Accountability Journal.Vol. 2.No. 1. pp: 36-51.

Brigham, Eugene F. dan Joel F. Houston. 2001. Manajemen Keuangan. Jakarta: Erlangga. Deegan, C. dan Rankin,M. 1996. Do Australian companies 
report environmental news objectively. Accounting, Auditing \& Accountability Joumal.Vol. 9 No.2. pp: 50-67.

Dewi, N. P. M. S. 2015. Pengaruh Profitabilitas dan Kepemilikan Asing Pada Pengungkapan Corporate Social Responsibility. E- Jurnal Akuntansi Universitas Udayana, 13(1), 84 - 98.

Dewi, Sutrisna. 2010. Etika Bisnis. Denpasar: Udayana University Press.

Eddy Rismanda Sembiring. (2005). Karakteristik Perusahaan Dan Pengungkapan Tanggung Jawab Sosial: Study Empiris Pada Perusahaan Yang Tercatat Di Bursa Efek Jakarta. Makalah SNA IV.

Elkington, J. 1997.Cannibals with Forks: The Triple Bottom Line of 21st Century Business.Oxford: Capstone Publishing.

Fahmi, Irham. 2012. Analisis Kinerja Keuangan: Panduan Bagi Akademisi, Manajer, dan Investor Untuk Menilai dan Menganalisis Bisnis Dari Aspek Keuangan. Bandung: Alfabeta.

Fahmi, Irham. 2012. Manajemen Investasi : Teori dan Soal Jawab.Jakarta: Selembang Empat.

Fahrizqi, Anggara. 2010. Faktor-Faktor yang Mempengaruhi Pengungkapan Corporate Social Responsibility (CSR) dalam Laporan Tahunan Perusahaan (Studi Empiris pada Perusahaan Manufaktur yang Terdaftar dalam Bursa Efek Indonesia). Skripsi Sarjana Jurusan Akuntansi pada Fakultas Ekonomi Universitas Diponegoro. Semarang.

Freeman, R.E. dan J. McVea. 2001. "A Stakeholder Approach to Strategic

Management".http://papers.ssrn.com/sol3/papers.cfm?abstract_id=263511. SSRN. Diakses tanggal 25 Juli 2014.

Ghozali, I. dan A. Chariri. 2007. Teori Akuntansi. Semarang: Badan Penerbit Universitas Diponegoro.

Gray, R., R. Kouhy, dan S. Lavers. 1995. Corporate Social and Environmental Reporting. A Review of the Literature and a Longitudinal Study of UK Disclosure.Accounting, Auditing and Accountability Journal.Vol. 8.No. 2. pp: 47-77.

Indah Dewi Utami. 2005. Pengaruh Ukuran Perusahaan, Ukuran Dewan Komisaris, Kepemilikan Institutional, Kepemilikan Asing, Dan Umur Perusahaan Terhadap Corporate Sosial Responsibility Disclosure pada perusahaan property dan Real Estate yang terdaftar di Bursa Efek Indonesia. Jurnal Business Accounting. Vol 2

No 1. 
Jayanti, P. 2011. Analisis Pengaruh Size, Profitabilitas dan Leverage Terhadap Pengungkapan CSR Pada Perusahaan yang Terdaftar di Bursa Efek Indonesia. Skripsi Program Sarjana Fakultas Ekonomi Universitas Diponegoro.

Marzully, N., dan P. Denies. 2012. Analisis Faktor-Faktor Yang Mempengaruhi Pengungkapan Corporate Social Responsibility pada Perusahaan Manufaktur Yang Terdaftar di Bursa Efek. Jurnal Nominal 1(1):22-34.

Natalylova Kartina. 2013. Pengaruh Corporate Governance Terhadap Corporate social responsibility dan Kinerja Perusahaan Yang Mendapatkan Indonesia Sustainability Reporting Award. Media. Bisnis. Edisi Khusus November.

Nur dan Priantinah (2012). Analisis Faktor-Faktor Yang Mempengaruhi Pengungkapancorporate Social Responsibility Di Indonesia (Studi Empiris Pada Perusahaan Berkategori High Profile Yang Listing Di Bursa Efek Indonesia). Jurnal Nominal / Volume I Nomor I / Tahun 2012.

Oktariani.2014. Pengaruh Karakteristik Perusahaan dan Tanggung Jawab Lingkungan pada Pengungkapan Tanggung Jawab Sosial Perusahaan.EJurnal Akuntansi Universitas Udayana.h: 402-418.

Prihastuti, Theresia. 2008. Analisis Pengaruh Ukuran Perusahaan, Likuiditas, Leverage, dan Profitabilitas Terhadap Voluntary Disclosure (Study Empiris pada Perusahaan Manufaktur yang Tercatat di Bursa Efek Jakarta Tahun 2003-2006, Rangkuman Skripsi Sekolah Tinggi Ilmu Ekonomi Perbanas. Surabaya.

Purwanto, A. 2011. Pengaruh Tipe Industri, Ukuran Perusahaan,Profitabilitas terhadap Corporate Social Responsibility. Jurnal Akuntansi dan Auditing 8(1): 12-29.

Putri, Rafika Anggraini dan Yulius Jogi Christiawan. 2014. Pengaruh Profatibilitas, Likuiditas, dan Leverage terhadap Pengungkapan Corporate Social Responsibility (Studi pada Perusahaan-Perusahaan yang Mendapat Penghargaan ISRA dan Listed (Go-Public) di Bursa Efek Indonesia (Bei) 2010-2012). Jurnal Business Accounting Review.Vol. 2, No. 1.

Ramadhaningsih Amalia dan I Made Karya Utama. 2013. Pengaruh Indikator Good Corporate Governance dan Profitabilitas Pada Pengungkapan Corporate Social Responsibility. E-Journal Akuntansi Universitas Udayana. Bali.

Rawi dan Munawar Muchlish. 2010. Kepemilikan Manajemen, Kepemilikan Institusi, Leverage dan Corporate Social Responsibility. Simposium Nasional Akuntansi XII.Puwokerto. 
Rosyadi, Risky Latif. 2015. Pengaruh Ukuran Perusahaan, Profitabilitas, Likuiditas, dan Media Exposure Terhadap Pengungkapan Corporate Social Responsibility. Skripsi. Fakultas Ekonomi. Universitas Negeri Semarang.

Sari, R.A. 2012. Pengaruh Karakteristik Perusahaan terahadap Corporate Social Responsibility Disclousre pada Perusahaan Manufaktur Yang Terdaftar di Bursa Efek Indonesia. Jurnal Nominal 1(1): 124-140.

Sembiring, Eddy Rismanda. 2003. Kinerja Keuangan, Political Visibility, Ketergantungan pada Hutang, dan Pengungkapan Tanggung Jawab Sosial Perusahaan. Makalah disampaikan pada Simposium Nasional Akuntansi VI Surabaya, 16 17 Oktober 2003.

Sembiring, E. R. 2005. Karakteristik Perusahaan dan Pengungkapan Tanggung Jawab Sosial (Studi Empiris pada Perusahaan yang Tercatat di Bursa Efek Jakarta).Simposium Nasional Akuntansi 8. Solo.

Situsresmi: www.idx.co.id diakses Januari 2018.

Sjahrial, Dermawan, 2009. Manajemen Keuangan. Edisi Tiga. Jakarta: Mitra Wacana Media.

Sudarmadji, A.M dan L. Sularto. 2007. Pengaruh Karakteristik Perusahaan Terhadap Pengungkapan TanggungJawab Sosial Dalam Laporan Tahunan Perusahaan Yang Terdaftar Di Bursa Efek Indonesia. Prosiding PESAT (Psikologi, Ekonomi, Sastra, Arsitek dan Sipil). Auditorium Kampus Gunadarma: A53-A61.

Suhaenah. 2012. Analisis Pengaruh Ukuran Perusahaan, Profitabilitas Dan Leverage Terhadap Pengungkapan Tanggung Jawab Sosial Perusahaan (Corporate Social Responsibility Disclosure). Skripsi. Universitas Gunadarma.

Utama. S, Made. 2009. Aplikasi Analisis Kuantitatif. Edisi ketiga. Denpasar: FE Unud.

Untari, Lisna. 2010. "Effect On Company Characteristics Corporate Social Responsibility Disclosure In Corporate Annual Report Of Consumption Listed In Indonesia Stock Exchange”. Jakarta: Universitas Gunadarma. •

Wiagustini, Ni Luh Putu. 2010. Dasar-Dasar Manajemen Keuangan. Denpasar: Udayana University Press.

Widianingsih, Y. P. N. 2011. Pengaruh Likuiditas dan Profitabilitas terhadap Luas Pengungkapan Sukarela Laporan Tahunan Studi Empiris pada Perusahaan Manufaktur yang terdaftar di Bursa Efek Indonesia, Politeknosains Vol.X No.2, Surakarta. 